\title{
ANALISIS HUJAN ES DI KOTA LUBUKLINGGAU DENGAN MEMANFAATKAN DATA CITRA SATELIT HIMAWARI-8 DAN RADIOSONDE
}

\author{
Heriyanto Wicaksono, Fazrul Rafsanjani Sadarang, Ahmad Fadlan
}

Program Studi Meteorologi, Sekolah Tinggi Meteorologi Klimatologi dan Geofisika, Jl. Perhubungan I No. 5, Pondok Betung, Pondok Aren, Tangerang Selatan

Email : heriyanto1698@gmail.com

\begin{abstract}
The phenomenon of hail again hit Indonesia. The hail occurred in Lubuklinggau City, South Sumatra on October 15, 2018 at around 16.20 WIB. Based on AWS Tugu Mulyo observation data, the rainfall on 15 October 2018 was recorded at $26.8 \mathrm{~mm}$ which included the medium rainfall category according to BMKG. This research aims to analyze the state of the atmosphere, satellite imagery, sea surface temperature anomalies and air lability during the hailstorm in Lubuklinggau. Analysis of atmospheric conditions using air temperature data $(T)$, air humidity $(R H)$, and air pressure $(P)$ results of observations of the surface before, during, and after the event. The Himawari satellite image with a resolution of $0.02^{\circ} \times 0.02^{\circ}$ is processed with the SATAID application and is used to view the cloud growth phase. Air lability was analyzed by processing radiosonde data from Weather Wyoming Web using the RAOB application 5.7. The results of the analysis show that in the event of hail, the surface air temperature has decreased significantly, the surface air humidity has a significant increase, and the lowest surface air pressure is lower than the day before the hail. The air lability index shows that before the occurrence of hail, atmospheric conditions are unstable causing massive growth of convective clouds. The anomaly of sea surface temperature around Sumatra Island is quite warm, which is $0.5^{\circ} \mathrm{C} .1,8^{\circ} \mathrm{C}$ which results in the possibility of cloud formation around Sumatra Island getting bigger. Based on satellite imagery, the peak temperature of the cloud at $16.00 \mathrm{WIB}$ is $-10.3^{\circ} \mathrm{C}$ and at $16.10 \mathrm{WIB}$ the cloud peak temperature reaches $-67.8^{\circ} \mathrm{C}$. Significant decrease in cloud peak temperature in the 10-minute period indicates the presence of cloud growth due to a very strong updraft so that the peak temperature of the cloud becomes very cold. The temperature of the cloud peak reaching $-67.8^{\circ} \mathrm{C}$ shows that there is a convective cloud that is strong enough when there is hail in Lubuklinggau.
\end{abstract}

Keywords: hail, Himawari-8, lability index

\begin{abstract}
Abstrak: Fenomena hujan es kembali melanda Indonesia. Hujan es tersebut terjadi di Kota Lubuklinggau, Sumatra Selatan pada tanggal 15 Oktober 2018 sekitar pukul 16.20 WIB. Berdasarkan data pengamatan AWS Tugu Mulyo, curah hujan pada tanggal 15 Oktober 2018 tercatat sebesar 26,8 mm yang termasuk kategori hujan sedang menurut BMKG. Penelitian kali ini bertujuan untuk menganalisis keadaan atmosfer, citra satelit, anomali suhu permukaan laut, dan labilitas udara pada saat terjadi hujan es di Lubuklinggau. Analisis keadaan atmosfer menggunakan data suhu udara (T), kelembapan udara $(\mathrm{RH})$, dan tekanan udara $(\mathrm{P})$ hasil pengamatan permukaan sebelum, saat, dan sesudah kejadian. Citra satelit Himawari dengan resolusi $0.02^{\circ} \times 0.02^{\circ}$ diolah dengan aplikasi SATAID dan digunakan untuk melihat fase pertumbuhan awan. Labilitas udara dianalisis dengan mengolah data radiosonde dari Weather Wyoming Web menggunakan aplikasi RAOB 5.7. Hasil analisis menunjukkan bahwa pada saat terjadi hujan es, suhu udara permukaan mengalami penurunan yang signifikan, kelembapan udara permukaan mengalami kenaikan yang signifikan, serta tekanan udara permukaan terendah lebih rendah daripada hari sebelum terjadinya hujan es. Indeks labilitas udara menunjukkan bahwa sebelum terjadinya hujan es, kondisi atmosfer dalam keadaan labil sehingga menyebabkan pertumbuhan awan konvektif yang masif. Anomali suhu permukaan laut di sekitar Pulau Sumatera
\end{abstract}


cukup hangat, yaitu $0,5^{\circ} \mathrm{C}$ s.d. $1,8^{\circ} \mathrm{C}$ yang mengakibatkan peluang terbentuknya awan di sekitar Pulau Sumatera semakin besar. Berdasarkan citra satelit, suhu puncak awan pada jam 16.00 WIB sebesar $10,3^{\circ} \mathrm{C}$ dan pada jam $16.10 \mathrm{WIB}$ suhu puncak awan mencapai $-67,8^{\circ} \mathrm{C}$. Penurunan suhu puncak awan yang signifikan dalam kurun waktu 10 menit tersebut mengindikasikan adanya pertumbuhan awan akibat updraft yang sangat kuat sehingga suhu puncak awan menjadi sangat dingin. Suhu puncak awan yang mencapai $-67,8^{\circ} \mathrm{C}$ menunjukkan bahwa terdapat awan konvektif yang cukup kuat saat teradi hujan es di Lubuklinggau.

Kata kunci: hujan es, Himawari-8, indeks labilitas

\section{PENDAHULUAN}

Indonesia merupakan negara yang berada di wilayah khatulistiwa. Suhu permukaan yang tinggi akibat radiasi matahari yang terjadi sepanjang hari menjadi salah satu ciri wilayah khatulistiwa. Selain itu Indonesia juga terletak di daerah tropis yang suhu udaranya (di permukaan) selalu hangat dengan kelembaban udara yang relatif tinggi meskipun pada musim kemarau (Karmini, 2000). Tingginya pemanasan dan tersedianya banyak uap air secara fisis merupakan lahan subur bagi pertumbuhan awan-awan konvektif (Nurlatifah, 2012). Hal ini menyebabkan pembentukan awan secara konvektif menjadi pola utama pembentukan awan di Indonesia. Salah satu awan konvektif yang paling terkenal adalah jenis awan cumulonimbus $(\mathrm{Cb})$.

Awan cumulonimbus merupakan awan konvektif yang menjulang tinggi sebagai awan hujan yang disertai angin kencang dan petir. Tinggi dasar awan cumulonimbus antara 100-600 meter, sedangkan tinggi puncaknya dapat mencapai ketinggian $15 \mathrm{~km}$ atau ketinggian tropopause (Haryoko, 2009). Menurut (Haryoko, 2009), fase pertumbuhan awan cumulonimbus $(\mathrm{Cb})$ adalah sebagai berikut :

1. Pada fase tumbuh, awan calon cumulonimbus akan terlihat tumbuh pesat terutama komponen vertikalnya karena seluruh gerakan atau arus dalam pertumbuhan awan bergerak ke atas sehingga tubuhnya semakin besar dan dapat menjulang tinggi di angkasa sampai ketinggian $13 \mathrm{~km}$ (40 ribu kaki). Substansi awan ini, semuanya berupa butiran air sampai ketinggian $5 \mathrm{~km}$ dan butiran air campur salju (sampai puncaknya) sekitar $8 \mathrm{~km}$. Di daerah tropis, bentangan awan ini biasanya kurang dari $10 \mathrm{~km}$ (daerah tropis).

2. Fase dewasa atau matang tercapai jika puncak awan sudah membentuk landasan (bentuknya seperti tempaan sepatu) dengan bagian atas berbentuk datar karena awan padat ini mendapat tekanan dari tropopause yang sangat stabil dan panas. Substansi pada fase ini, butiran salju di bagian bawah, bagian tengah butiran air campur salju dan bagian puncak semuanya butiran es (kristal). Pada tahap ini pula, arus udara dalam tubuh awan naik (updraft) dan turun (downdraft) sehingga kristal-kristal es bisa menembus bagian bawah dan tengah. Dari sinilah lahirnya mekanisme hujan es (hail).

3. Fase pelenyapan, ditandai dengan adanya arus udara ke bawah yang lemah diseluruh sel. Fase ini disertai dengan intensitas hujan yang makin menurun dari hujan sedang menuju hujan ringan..

Menurut Peraturan Kepala Badan Meteorologi, Klimatologi, dan Geofisika Nomor : Kep. 009 Tahun 2010 tentang Prosedur Standar Operasional Pelaksanaan Peringatan Dini, Pelaporan, dan Diseminasi Informasi Cuaca Ekstrim, hujan es adalah hujan yang berbentuk butiran es yang mempunyai garis tengah paling rendah 5 (lima) milimeter ( $\mathrm{mm}$ ) dan berasal dari awan cumulonimbus. 
Hujan es merupakan bentuk presipitasi berupa bola-bola, potongan, maupun butir-butir es yang terpisah-pisah atau bergabung menjadi gumpalan dan memiliki diameter antara 5-50 mm (Fadholi, 2012; Wirjohamidjojo, 2009). Hujan es terbentuk dari sistem konvektif kuat dimana batuan es yang jatuh pada saat hujan es disebut hailstone (Fadholi, 2012). Hujan es terjadi pada daerah dengan ketinggian freezing level yang rendah, dimana ketika partikel es melalui freezing level dilapisan ketinggian yang cukup rendah maka partikel es tersebut akan mengalami proses pelelehan dan gesekan dengan partikel udara yang hanya sesaat sehingga ketika mencapai permukaan bumi, bentuknya masih akan berupa batuan es atau hailstone (Ali, 2015).

Freezing level adalah ketinggian di lapisan atmosfer dengan suhu $0^{\circ} \mathrm{C}$ yang membuat tetestetes air berubah menjadi es. Di wilayah tropis, ketinggian freezing level cukup tinggi, yaitu antara 4500 sampai dengan 5000 meter dengan variabilitas bulanan dan tahunan yang rendah, sedangkan ketinggian freezing level di wilayah ekstra-tropis lebih rendah daripada wilayah tropis dengan variabilitas bulanan dan tahunan yang tinggi (Harris dkk, 1998). Pada umumnya, hidrometeor yang jatuh ke permukaan bumi memiliki diameter yang sama, baik di wilayah tropis maupun di wilayah ekstra-tropis. Akan tetapi, karena wilayah tropis memiliki freezing level yang tinggi, maka selama partikel es jatuh, partikel es tersebut akan meleleh karena bergesekan dengan udara di atmosfer, sehingga saat mencapai permukaan bumi akan mencair menjadi air hujan.

Hujan es terbentuk pada awan comulonimbus ketika puncak awan tersebut telah melewati freezing level. Agar terbentuk awan cumulonimbus, kondisi atmosfer harus mendukung dengan labilnya lapisan udara sehingga mudah terjadi proses konveksi. Selain itu, harus ada suplai uap air yang cukup sehingga massa udara yang terangkat oleh proses konveksi mengandung uap air yang banyak dan akan mempermudah terbentuknya awan cumulus yang berkembang menjadi awan cumulonimbus (Karmini, 2000).

SATAID (Satellite Animation and Interactive Diagnosis) merupakan software yang dikembangkan oleh Japan Meteorology Agency (JMA) dan berfungsi untuk mengambil data parameter meteorologi dari citra satelit. SATAID mengolah data binari dari satelit kemudian merubahnya menjadi gambar. Selain itu, SATAID juga digunakan untuk menampilkan citra satelit dan menghampar (overlay) data prediksi cuaca numerik NWP (Numerical Weather Prediction). Dengan menggunakan SATAID, pengguna dapat menampilkan dan melakukan overlay antara citra satelit dan data NWP.

Tujuan penelitian ini adalah untuk mengetahui dan menganalisis keadaan atmosfer, citra satelit, anomali suhu permukaan laut, dan labilitas udara pada saat terjadi hujan es di Lubuklinggau.

\section{METODE PENELITIAN}

Data yang digunakan dalam penelitian ini antara lain : data pengamatan sinoptik pada tanggal 14 sampai dengan 16 Oktober 2018 pukul 00 UTC sampai dengan 23 UTC yang diperoleh dari AWS Tugu Mulyo; data citra satelit Himawari-8 kanal infrared dengan panjang gelombang $3.9 \mu \mathrm{m}$ (I4), $6.2 \mu \mathrm{m}$ (WV), $7.3 \mu \mathrm{m}$ (W3), $10.8 \mu \mathrm{m}$ (IR), near infrared dengan panjang gelombang $1.6 \mu \mathrm{m}$ (N2), serta visible dengan panjang gelombang $0.64 \mu \mathrm{m}$ (VS) tanggal 15 Oktober 2018 pukul 05 UTC sampai dengan 13 UTC dengan resolusi $0.02^{\circ} \mathrm{x}$ $0.02^{\circ}$ yang diperoleh dari BMKG Bidang Pengelolaan Citra Inderaja; data radiosonde pada tanggal 14 sampai dengan 16 Oktober 2018 pukul 00 dan 12 UTC yang diperoleh dari Wyoming Weather Web (http://weather.uwyo.edu/upperair/sounding.html); serta data anomali suhu permukaan laut dengan resolusi $0.05^{\circ}$ x $0.05^{\circ}$ pada tanggal 15 Oktober 2018 
yang

diperoleh

dari

NOAA

(ftp://ftp.star.nesdis.noaa.gov/pub/sod/mecb/crw/data/5km/v3/nc/v1/daily/ssta/2018/).

Data hasil pengamatan sinoptik diolah dengan Microsoft Excel untuk menampilkan grafik parameter tersebut terhadap waktu. Kondisi cuaca permukaan pada tanggal 14 dan 16 Oktober 2018 yang merupakan hari tanpa hujan dibandingkan dengan hari kejadian hujan es yaitu tanggal 15 Oktober 2018.

Data citra satelit Himawari-8 kanal 13 (IR $10.8 \mu \mathrm{m}$ ) diolah dengan aplikasi SATAID untuk melihat pertumbuhan awan saat kejadian hujan es dengan memperhatikan time series suhu puncak awan. Data tersebut juga diolah dengan aplikasi GrADS untuk memetakan suhu puncak awan. Selain itu, untuk menentukan awan Cumulunimbus, digunakan teknik RGB dengan memanfaatkan 6 kanal dari satelit Himawari-8. 6 kanal tersebut antara lain kanal infrared dengan panjang gelombang $3.9 \mu \mathrm{m}$ (I4), $6.2 \mu \mathrm{m}$ (WV), $7.3 \mu \mathrm{m}$ (W3), $10.8 \mu \mathrm{m}$ (IR), near infrared dengan panjang gelombang $1.6 \mu \mathrm{m}$ (N2), serta visible dengan panjang gelombang $0.64 \mu \mathrm{m}$ (VS).

Untuk menganalisis kondisi labilitas udara pada hari saat kejadian hujan es, data radiosonde diolah dengan menggunakan RAOB 5.7. Hasil pengolahan data tersebut berupa nilai SI, LI, KI, TTI, Sweat-Index, CAPE, dan CIN, serta digunakan untuk menentukan ketinggian freezing level.

Data anomali suhu permukaan laut pada tanggal 15 Oktober 2018 diolah dan dipetakan dengan aplikasi GrADS. Anomali suhu permukaan laut yang positif menunjukkan suhu laut yang hangat dan berpotensi menimbulkan pembentukan awan.

\section{HASIL DAN PEMBAHASAN}

\subsection{Analisis Kondisi Cuaca Permukaan}

Gambar 2 merupakan hari saat kejadian hujan es, yaitu tanggal 15 Oktober 2018. Gambar 1 dan Gambar 3 merupakan hari sebelum dan sesudah kejadian hujan es, yaitu tanggal 14 Oktober 2018 dan 16 Oktober 2018 yang merupakan hari tanpa hujan.

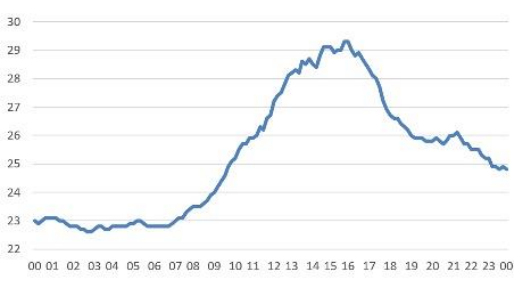

(a)

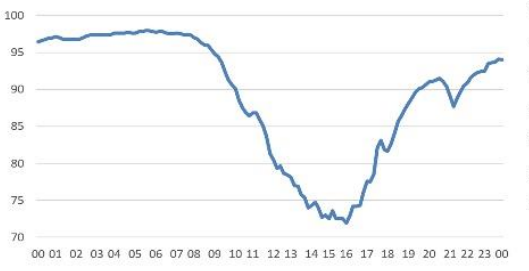

(b)

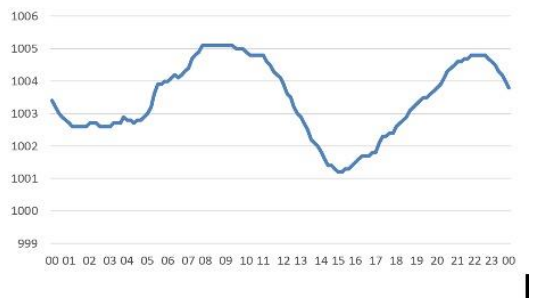

(c)

Gambar 3. Grafik Time Series (a) Suhu, (b) Kelembapan, dan (c) Tekanan Udara di Kota Lubuklinggau Pada Tanggal 14 Oktober 2018 


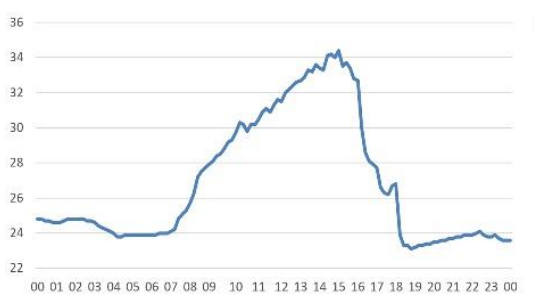

(a)

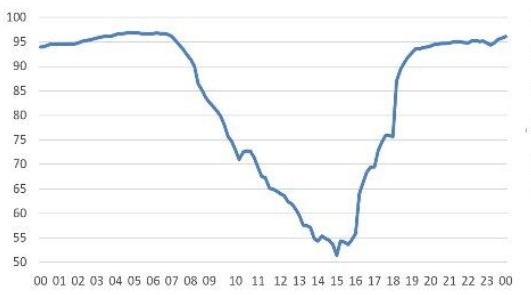

(b)

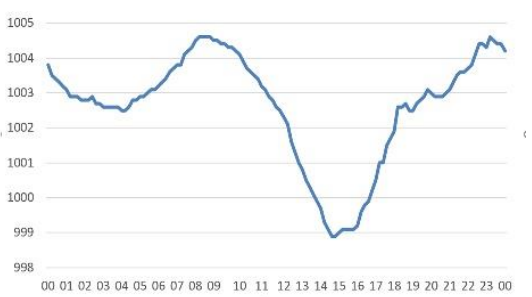

(c)

Gambar 2. Grafik Time Series (a) Suhu, (b) Kelembapan, dan (c) Tekanan Udara di Kota Lubuklinggau Pada Tanggal 15 Oktober 2018

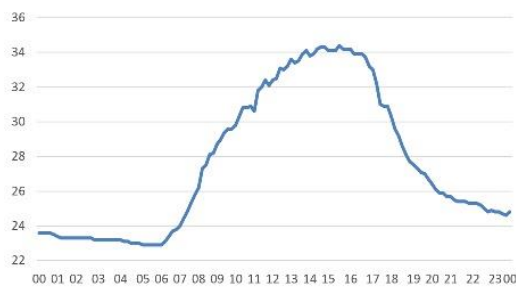

(a)

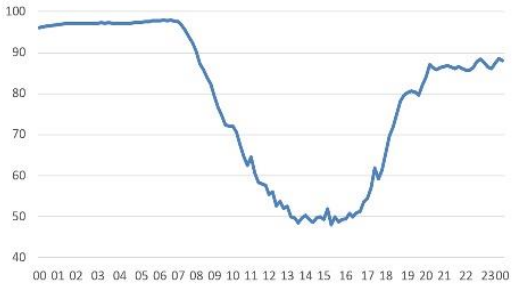

(b)

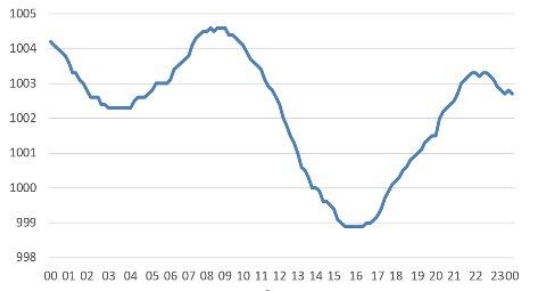

(c)

Gambar 3. Grafik Time Series (a) Suhu, (b) Kelembapan, dan (c) Tekanan Udara di Kota Lubuklinggau Pada Tanggal 16 Oktober 2018

Pada tanggal 14 dan 16 Oktober 2018, suhu udara mengalami kenaikan secara perlahan hingga mencapai puncaknya sekitar jam 13.00 WIB sampai 14.00 WIB. Setelah itu, saat menuju sore hari, suhu mengalami penurunan secara perlahan akibat dari radiasi matahari yang semakin berkurang. Grafik kelembapan udara menunjukkan penurunan secara perlahan saat memasuki siang hari. Penurunan ini diakibatkan karena kadar uap air di udara semakin berkurang. Kelembapan udara akan kembali meningkat ketika menuju sore hari. Pola grafik tekanan pada hari tanpa hujan ditandai dengan dua puncak, dimana puncak pertama lebih tinggi daripada puncak kedua.

Pada tanggal 15 Oktober 2018 yang merupakan hari saat kejadian hujan es, terjadi kenaikan suhu hingga $34^{\circ} \mathrm{C}$. Kenaikan suhu tersebut memicu adanya peningkatan proses pemanasan dan penguapan, serta mengindikasikan bahwa suhu di permukaan lebih hangat dibandingkan dengan suhu atmosfer. Akibatnya keadaan atmosfer sebelum hujan es menjadi labil. Ketika sudah memasuki waktu hujan es, suhu udara mengalami penurunan suhu yang drastis pada pukul 16.00 WIB hingga 18.00 WIB. Penurunan suhu ini dipicu karena tutupan awan di langit serta menandai proses hujan sedang berlangsung. Selain itu, ketika terjadi hujan es, kelembapan udara naik secara signifikan mulai pukul 16.00 WIB hingga 18.00 WIB yang menunjukkan bahwa kadar uap air di udara semakin meningkat akibat pemanasan oleh matahari. Pola grafik tekanan pada hari tanpa hujan ditandai dengan dua puncak, dimana tinggi puncak pertama hampir sama dengan puncak kedua. Kondisi perubahan tekanan hampir sama dengan kasus kejadian hujan es yang diteliti oleh Fadholi (2012) dan Hidayati (2015) di Bandung. Pada penelitian tersebut, pola tekanan pada saat hari tanpa hujan menunjukkan pola dengan dua puncak, dimana puncak pertama lebih tinggi daripada puncak kedua, sedangkan saat terjadi hujan es menunjukkan pola dengan dua puncak, dimana tinggi puncak pertama lebih rendah dengan puncak kedua. 
Dari analisis diatas, kejadian hujan es diindikasikan terjadi antara pukul 16.00 WIB hingga 18.00 WIB. Pada waktu tersebut, kondisi atmosfer saat hujan es berbeda dengan kondisi atmosfer saat hari tanpa hujan.

\subsection{Analisis Citra Satelit Himawari-8}
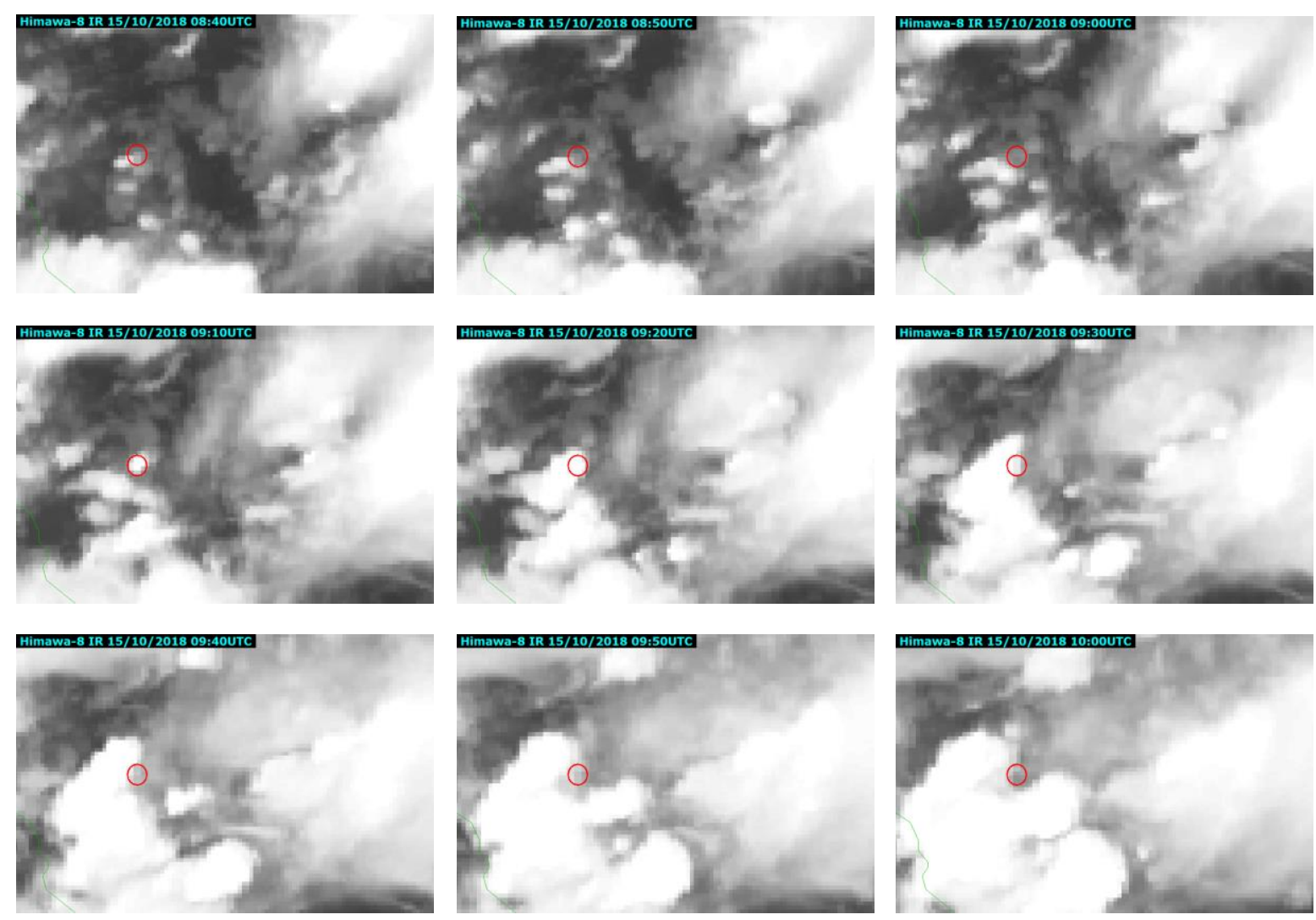

Gambar 4. Citra Satelit Himawari-8 kanal infrared dengan panjang gelombang $10.8 \mu \mathrm{m}$ di sebagian wilayah Sumatera Selatan pada tanggal 15 Oktober 2018 jam 08.40 UTC s.d 10.00 UTC dengan interval 10 menit. Lingkaran merah merupakan wilayah Kabupaten

\section{Lubuklinggau.}

Pada Gambar 4, terlihat bahwa Kota Lubuklinggau hanya tertutup oleh awan rendah pada pukul 08.40, 08.50, dan 09.00 UTC. Pada pukul 09.10 UTC, awan tinggi atau tebal mulai menutupi wilayah Kota Lubuklinggau. Awan semakin berkembang luas saat memasuki 09.20 UTC. Akibat pergerakan angin dari arah timur, awan tebal sedikit bergeser ke arah barat, sehingga pada pukul 10.00 UTC wilayah Kota Lubuklinggau hanya ditutupi oleh awan rendah. 


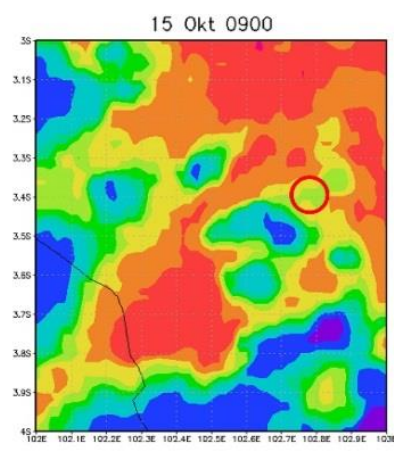

15 Okt 0930

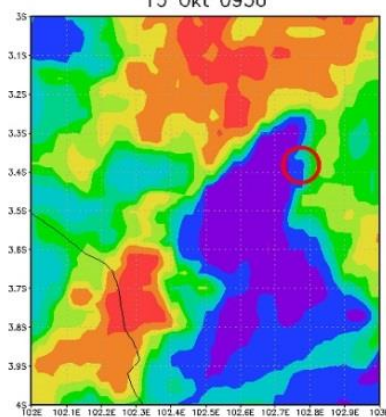

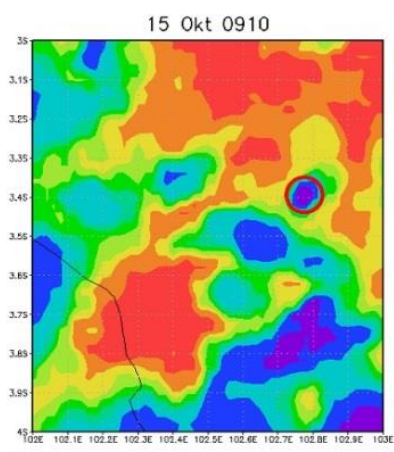

15 Okt 0940

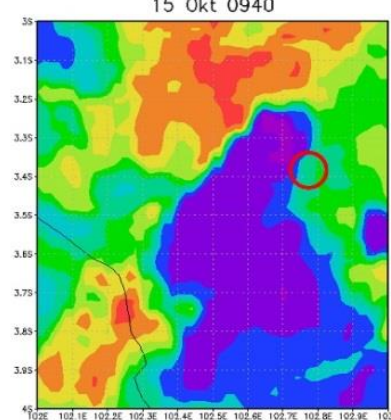

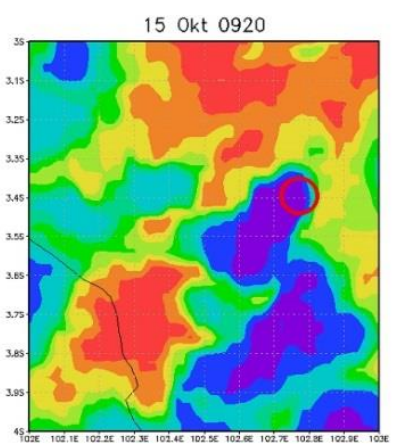

15 Okt 0950

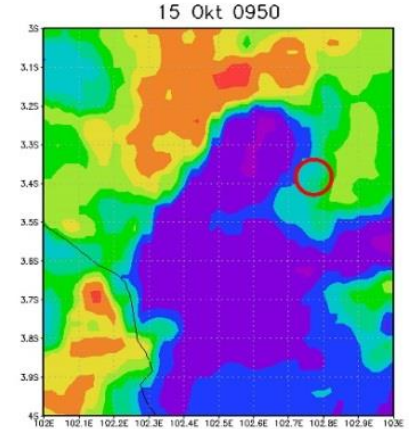

Gambar 5. Peta suhu puncak awan di sebagian wilayah Sumatera Selatan pada tanggal 15 Oktober 2018 pukul 09.00 sampai dengan 09.50 UTC. Lingkaran merah merupakan wilayah Kabupaten Lubuklinggau.

Pada Gambar 5 terlihat bahwa saat terjadi hujan es, suhu puncak awan mencapai kurang dari $-60^{\circ} \mathrm{C}$ di Kota Lubuklinggau. Pertumbuhan awan semakin besar hingga pukul 09.50 UTC.

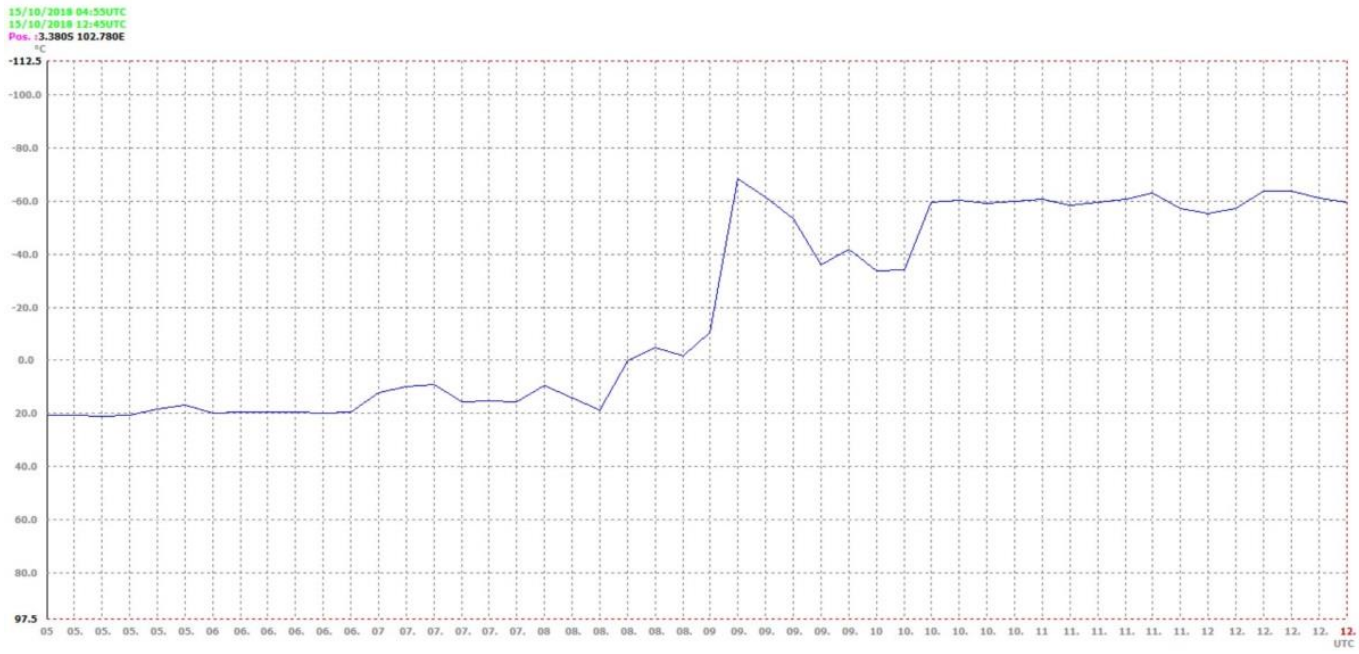

Gambar 6. Grafik Time Series Suhu Puncak Awan di Kabupaten Lubuklinggau.

Dari Gambar 6, terlihat bahwa telah terjadi pertumbuhan awan konvektif yang ditandai dengan turunnya suhu secara signifikan dari $-10,3{ }^{\circ} \mathrm{C}$ pada pukul $09.00 \mathrm{UTC}$ (16.00 WIB) menjadi $-67,8^{\circ} \mathrm{C}$ pada pukul 09.10 UTC (16.10 UTC). 
Untuk memastikan apakah awan yang tumbuh saat pukul 09.10 dan 09.20 UTC merupakan awan tinggi seperti cirrus atau justru awan cumulonimbus, digunakan teknik RGB dengan mengkombinasikan 6 kanal dari citra satelit Himawari-8. Nilai-nilai yang digunakan dalam teknik RGB bersumber dari Japan Meteorological Agency. Gambar 7 merupakan citra RGB satelit Himawari-8.
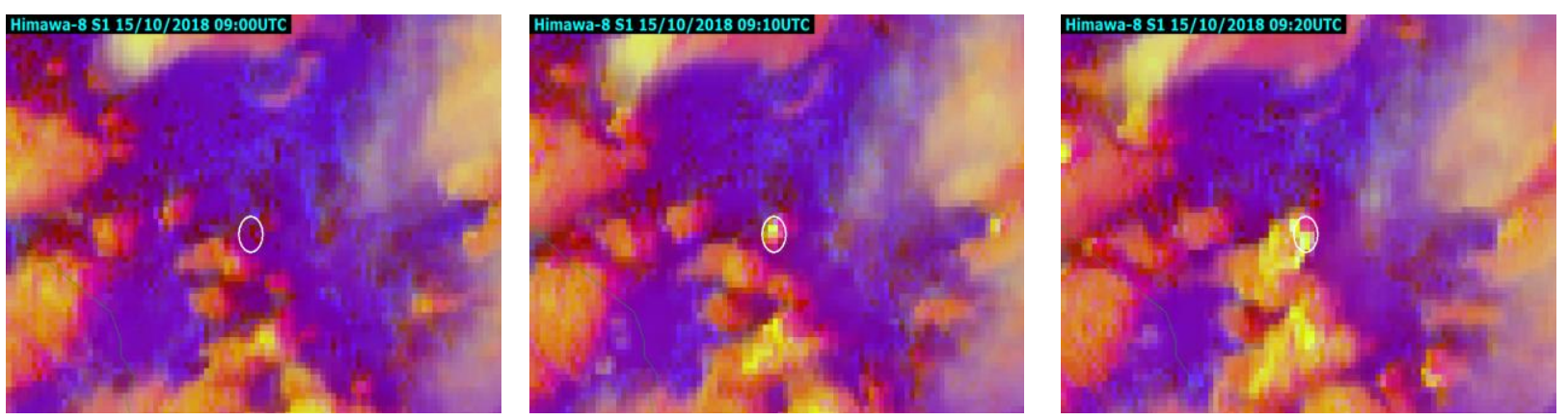

Gambar 7. Citra RGB Satelit Himawari-8 di sebagian wilayah Sumatera Selatan pada tanggal 15 Oktober 2018 jam 08.40 UTC s.d 10.00 UTC dengan interval 10 menit.

Pada Gambar 7, terlihat bahwa pada jam 09.10 dan 09.20 UTC wilayah Kota Lubuklinggau tertutupi oleh awan berwarna kuning. Warna kuning menunjukkan bahwa di wilayah tersebut terdapat awan pembentuk presipitasi, yaitu awan cumulonimbus dengan aliran udara yang kuat serta berpotensi terjadi cuaca buruk, dan awan tinggi dengan partikel es kecil. Adanya awan cumulonimbus berpotensi menimbulkan hujan lebat disertai hujan es.

\subsection{Analisis Labilitas Atmosfer}

Tabel 1. Indeks Labilitas Udara di Kota Lubuklinggau

\begin{tabular}{cc}
\hline Indeks & Nilai \\
\hline SI & $-0,39$ \\
LI & $-2,78$ \\
SWEAT & 200,18 \\
KI & 32,2 \\
TTI & 44,7 \\
CAPE & 869,41 \\
CIN & $-4,9$
\end{tabular}

Tabel 1 merupakan data radiosonde dari Weather Wyoming Web yang diolah menggunakan RAOB 5.7. Data radiosonde tersebut diambil dari Stasiun Meteorologi Bengkulu (WMO 96253) disajikan pada Tabel 1. Pada tanggal 15 Oktober 2018 pada jam 00 UTC atau jam 07.00 WIB, diperoleh nilai Showalter Index (SI) -0,39 yang berarti udara tidak stabil, nilai Lifted Index (LI) -2,78 yang berarti udara tidak stabil serta memungkinkan terbentuk awan konvektif, nilai $K$ Index (KI) 32,2 yang berarti kemungkinan terjadinya thunderstorm $60-80 \%$, nilai Total-totals Index (TT) 44,7 yang berarti kemungkinan tidak terjadi petir, nilai Severe Weather Threat Index (SWEAT) 200,18 yang berarti masuk kategori menengah untuk kemungkinan terjadi cuaca buruk, dan nilai Convective Available Potential Energy Index (CAPE) $869,41 \mathrm{~J} / \mathrm{Kg}$ yang berarti kemungkinan kecil terjadi badai petir. Pada pagi hari kondisi labilitas atmosfer sudah menunjukkan potensi yang cukup besar bagi pertumbuhan awan konvektif. 


\subsection{Analisis Anomali Suhu Permukaan Laut}

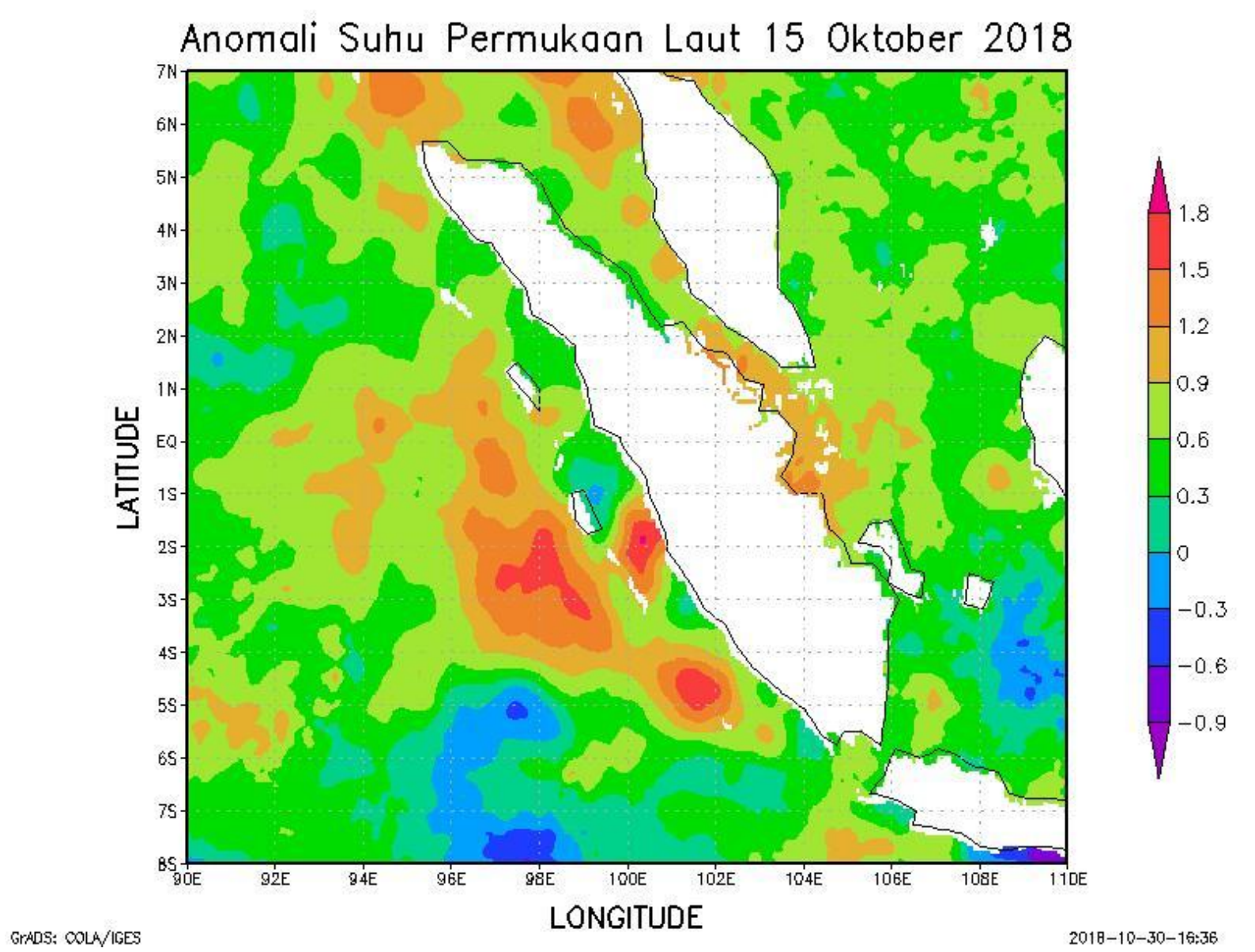

Gambar 8. Anomali suhu permukaan laut di perairan sekitar Pulau Sumatera

Dari Gambar 8 terlihat bahwa anomali suhu muka laut di sekitar Pulau Sumatera memiliki nilai 0,5 sampai 1,8 . Nilai anomali suhu yang positif menunjukkan bahwa suhu muka laut pada tanggal 15 Oktober 2018 cukup hangat dan mengakibatkan peluang terbentuknya awan di sekitar Pulau Sumatera semakin besar.

\section{KESIMPULAN}

Berdasarkan analisis yang telah dilakukan, dapat disimpulkan sebagai berikut.

a. Kondisi atmosfer di permukaan saat terjadi hujan es, yaitu pada tanggal 15 Oktober 2018 mengalami perbedaan dengan kondisi atmosfer pada tanggal 14 dan 16 Oktober 2018. Pada tanggal 15 Oktober 2018, suhu udara mengalami penurunan suhu yang drastis pada pukul 16.00 WIB hingga 18.00 WIB dan sebaliknya, kelembapan udara mengalami kenaikan secara signifikan. Kondisi ini mengindikasikan bahwa antara pukul 16.00 WIB hingga 18.00 WIB sedang terjadi cuaca bermakna.

b. Citra satelit menunjukkan terdapat tutupan awan tebal dan tinggi pada pukul 09.10 UTC hingga pukul 09.20 UTC di atas wilayah Kota Lubuklinggau. Awan tersebut terus bergerak ke arah barat. Dari hasil kombinasi 6 kanal citra satelit Himawari-8, terlihat bahwa terdapat awan cumulonimbus yang tumbuh di atas wilayah Kota Lubuklinggau. 
c. Suhu puncak awan mengalami penurunan secara signifikan dari $-10,3{ }^{\circ} \mathrm{C}$ pada pukul 09.00 UTC (16.00 WIB) menjadi $-67,8^{\circ} \mathrm{C}$ pada pukul 09.10 UTC (16.10 UTC). Penurunan ini mengindikasikan terjadinya pertumbuhan awan konvektif yang masif.

d. Sebagian besar indeks labilitas atmosfer pada tanggal 15 Oktober 2018 pukul 00 UTC menunjukkan bahwa kondisi atmosfer dalam keadaan labil. Kondisi udara bisa semakin tidak stabil saat memasuki siang hari karena mendapat energi tambahan dari radiasi matahari.

e. Anomali suhu permukaan laut di sekitar Pulau Sumatera menunjukkan angka yang postif, yaitu $+0,5$ s.d. $+1,8$. Anomali suhu muka laut yang positif mengakibatkan laut menjadi hangat dan berpotensi terjadi pertumbuhan awan-awan konvektif.

\section{SARAN}

Pada penelitian tentang hujan es selanjutnya, akan lebih baik jika menggunakan data radar, karena data radar dapat memberikan gambaran secara jelas fenomena yang terjadi di dekat permukaan.

\section{DAFTAR PUSTAKA}

Al Mughozali, Shandy, Prasetyo Umar Firdianto, dan Amir Mustofa Irawan. (2017). Analisis Hujan Lebat dan Angin Kencang di Wilayah Banjarnegara Study Kasus Rabu 8 November 2017. Unnes Physics Journal 6 (1), 65-69.

Ali, Abdullah. (2015). Identifikasi Kejadian Hujan Es Menggunakan Radar Cuaca Doppler. Prosiding Seminar Nasional Sains Atmosfer 2015. LAPAN : Bandung.

Bradley, Raymond S., Frank T. Keimig, Henry F. Diaz, Dan Douglas R. Hardy. (2009). Recent Changes in Freezing Level Heights in The Tropics with Implications for The Deglacierization of High Mountain Regions. Geophysical Research Letters, Vol. 36.

Dewita, Anggi, \& Khafid Dwicahyo. (2016). Analisis Banjir dengan Menggunakan SATAID (Studi Kasus: Banjir Ende, 31 Januari 2016). Prosiding Seminar Nasional Penginderaan Jauh -2016.

Fadholi, Ahmad. (2012). Analisa Kondisi Atmosfer pada Kejadian Cuaca Ekstrem Hujan Es (Hail). Simetri, Jurnal Ilmu Fisika Indonesia, 1 (2(D)), 74-80.

Haryoko, Urip.(2009). Laporan Kejadian Angin Kencang di Wilayah DKI Jakarta Tanggal 22 April 2009. Tangerang: BMKG.

Harris, Gettys N. Jr., Kenneth P. Bowman, Dan Dong-Bin Shin. (2000). Comparison of Freezing-Level Altitudes from the NCEP Reanalysis with TRMM Precipitation Radar Brightband Data. Journal of Climate Volume 13, 4137-4148.

Hidayati , Rahmah, Taufik Ramlan Ramalis, Muhammad Iid Mujtahiddin. (2015). Analisis Kejadian Hujan Es di Wilayah Bandung Berdasarkan Kondisi Atmosfer dan Citra Satelit. Fibusi (JoF) Vol. 3 No. 1.

Karmini, Mimin. (2000). Hujan Es (Hail) di Jakarta, 20 April 2000. Jurnal Sains \& Teknologi Modifikasi Cuaca vol. 1 no. 1, 27-32.

Lestari, Rizka Erwin, Ejha Larasati Siadari, \& Ambinari Rachmi Putri. (2016). Analisis Kejadian Cuaca Ekstrem Hujan Es Di Kota Medan (Studi Kasus Tanggal 26 Juli 2015 Dan 12 September 2016). Prosiding Seminar Nasional Fisika Dan Aplikasinya, 
Bale Sawala Kampus Universitas Padjadjaran, Jatinangor

Meteorological Satelite Center (MSC) of JMA, RGB Composite Imagery. Diunduh dari http://www.data.jma.go.jp/mscweb/en/VRL/VLab_RGB/RGBimage.html

Nurlatifah, Sri. ( 2012). Pemanfaatan Data Satelit Cuaca MTSAT Untuk Estimasi Curah Hujan di Stasiun Meteorologi Tegal dan Stasiun Meteorologi Citeko, Tugas Akhir, AMG, Jakarta.

Nurrohman, Faqih \& Bayong Tjasyono. (2016). Kajian Indeks Stabilitas Atmosfer Terhadap Kejadian Hujan Lebat di Wilayah Makassar (Studi Kasus Bulan Desember 2013 2014). Jurnal Meteorologi Klimatologi dan Geofisika Vol. 3 No.2, 18-24.

Tahmid, Muhammad. (2017). Profil Klimatologis Ketinggian Freezing Level di Wilayah Medan, Padang, Jakarta, Palu, dan Ambon, Skripsi, STMKG, Jakarta.

Wilson, G.S., dan Scoggins, J.R. (1976). Atmospheric Structure And Variability In Areas Of Convective Storms Determined From 3-H Rawinsonde Data. NASA CR-267 8, 128 pp. [NTIS, Springfield, VA 22161].

Zahroh, Nyayu Fatimah, Ni Wayan Srimani Puspa Dewi, \& Dini Harsanti. (2017). Indeks Labilitas Udara Untuk Memprediksi Kejadian Badai Guntur Pada Periode Puncak Musim Hujan Tahun 2016. Jurnal Sains \& Teknologi Modifikasi Cuaca, Vol.18 No.1, 9-15. 